Case Study

\title{
Effects of double air-cushion biofeedback exercises in a patient with sacroiliac joint pain
}

\author{
WON-GYU YOO ${ }^{1)}$ \\ 1) Department of Physical Therapy, College of Biomedical Science and Engineering, Inje University: \\ 607 Obangdong, Gimhae, Gyeongsangnam-do 621-749, Republic of Korea
}

\begin{abstract}
Purpose] We developed a double air-cushion biofeedback device to be used for sacroiliac (SI) joint exercises and investigated the effects of exercising using the device in a patient with SI joint pain. [Subject] A 40-year-old man, who complained of pain in the left posterior iliac crest area and SI joints over a 6-month period participated. [Methods] After a 4-week exercise program using the double air-cushion biofeedback device, the subject was assessed using the Gaenslen, Patrick, posterior shear (POSH), and resisted abduction (REAB) tests. [Results] After performing exercise designed to strengthen subdivisions of the gluteus medius, the subject had no pain in the Gaenslen, Patrick, POSH, or REAB tests of the SI joint. The visual analog scale (VAS) score for pain on palpation of the left posterior iliac crest area decreased to $4 / 10$ from an initial score of $7 / 10$. [Conclusion] Exercises with the double air-cushion biofeedback device improved hip asymmetry, SI joint mobility, and muscle strength. Key words: Biofeedback, Pain-provocation tests, Sacroiliac joint pain
\end{abstract}

(This article was submitted Jul. 13, 2015, and was accepted Aug. 19, 2015)

\section{INTRODUCTION}

The bone in the sacroiliac (SI) joints is covered with a cartilage layer that allows some movement and acts as a shock absorber ${ }^{1,2)}$. When this cartilage is damaged or worn away, the bones begin to rub on each other, leading to arthritis. This is the most common cause of SI joint dysfunction ${ }^{1-3)}$. Degenerative arthritis is common in the SI and other weightbearing joints. SI joint pain occurs when leaning forward to perform lifting, bending, or lowering motions, moving the line of gravity anterior toward the acetabular axis ${ }^{2}$. SI joint pain suggests that nociceptive and painful mechanical stress within the SI joint or acting on the surrounding tissues attached to the innominate bones is caused by pelvic asymmetry or SI joint instability ${ }^{3}$. SI joint dysfunction is common in athletes and the general population because the SI joint links the spine and lower extremities, and high loads are transferred through the lumbar spine and pelvis during athletic activity ${ }^{3)}$. In this study, we developed a double air-cushion biofeedback device for SI joint exercises, and investigated the effects of exercising using the device in a patient with SI joint pain.

Corresponding author. Won-gyu Yoo (E-mail: won7y@inje. ac.kr)

C2015 The Society of Physical Therapy Science. Published by IPEC Inc. This is an open-access article distributed under the terms of the Creative Commons Attribution Non-Commercial No Derivatives (by-ncnd) License $<$ http://creativecommons.org/licenses/by-nc-nd/3.0/>.

\section{SUBJECT AND METHODS}

A 40-year-old man who complained of pain in the left posterior iliac crest area and SI joints over a 6-month period participated. The study purpose and methods were explained to the subject, who provided informed consent according to the principles of the Declaration of Helsinki before participating. When bending his waist, he felt SI joint pain. Severe pain also occurred in the left posterior iliac crest area and SI joints after standing for 1 hour or after walking for 30 min. We developed a double air-cushion biofeedback device for SI joint exercises. The device consisted of two 20 $\times 10 \mathrm{~cm}$ air cushions containing pressure-detecting sensors (AP-series pressure sensors, Keyence, Japan). The subject was provided visual feedback using displays linked to the pressure sensors. The two air cushions were positioned between the left and right hip joints and a seat support. The air cushion positions on the support board could be adjusted with Velcro. The pressure sensors could sense the air pressure within the air cushion. Exercise 1 involved maintaining the same air pressure on both sides while in a sitting posture during a leg-raising exercise with knee flexion at $90^{\circ}$ and an erect sitting posture using the device. A therapist instructed the subject and defined success and failure at maintaining the air pressure balance on both sides. The subject performed the exercise successfully 30 times each for the left and right leg-raising exercises in the sitting position. Exercise 2 involved lateral pelvic rotation. The subject performed on one side and the opposite side was lifted; this depressing double air-cushion biofeedback device on one side. The therapist instructed the subject to maintain the air pressure on the depressed side at twice the value for the lifted side. Again, the therapist instructed and defined success and failure at 
maintaining the appropriate air pressures on both sides. The subject performed the exercise successfully 30 times each for the left and right sides. All exercises consisted of three sets of 15 repetitions per day over 4 weeks.

The subject was assessed before and after the 4-week exercise program using a visual analog scale (VAS), with 0 representing no pain and 10 representing the worst imaginable pain and with the posterior shear (POSH), and resisted abduction (REAB) tests.

\section{RESULTS}

Before the 4-week exercise program with the double air-cushion biofeedback device, pain-provocation tests reproduced the pain at both SI joints. For the right SI joint, the Gaenslen, Patrick, and REAB tests gave positive results. For the left SI joint, he experienced pain with the Gaenslen, Patrick, and REAB tests. The patient rated his response to palpation of the left posterior iliac crest area in the prone position as $7 / 10$ on a VAS.

After the 4-week exercise program, the subject showed no SI joint pain in the Gaenslen, Patrick, POSH, or REAB tests. The VAS score was less the $4 / 10$ on palpation of the left posterior iliac crest area, compared with an initial score of $7 / 10$.

\section{DISCUSSION}

This study investigated the effects of a double air-cushion biofeedback device used during exercises for a patient with SI joint pain. After exercising for 4 weeks, the subject showed no pain in pain-provocation tests of the SI joint (the Gaenslen, Patrick, POSH, or REAB tests), and his VAS score decreased from $7 / 10$ to $4 / 10$.

The stability of the SI joint is increased by nutation torque, which is produced by three factors: hip joint compression due to body weight (i.e., by gravity); passive tension of stretched ligaments; and active muscle force ${ }^{4)}$. Exercises 1 and 2, conducted in a sitting position, would produce hip joint compression from body weight (gravity) because the ischial tuberosity is fixed on the seat support. The double air-cushion biofeedback device should improve the passive tension of stretched ligaments and active muscle forces. Biofeedback is an effective intervention for re-educating patients on posture and reducing the altered activation of muscles ${ }^{5)}$. SI joint dysfunction is a pathological release of the self-bracing position with anterior pelvic rotation ${ }^{2)}$. A shortened hamstring muscle pulls the ischial tuberosity inferiorly during forward bending, reducing the anterior tilt of the pelvis ${ }^{6}$. Yoo showed that exercises designed to strengthen the gluteus medius were effective at reducing SI joint pain ${ }^{7)}$. There is a relationship between the SI joint and limited hip mobility ${ }^{8}$. Patients with SI joint dysfunction also have asymmetric hip mobility with reduced abduction and lateral rotation ${ }^{8)}$. Exercises 1 and 2 with the device should improve hip asymmetry, SI joint mobility, and muscle strength.

\section{REFERENCES}

1) Zelle BA, Gruen GS, Brown S, et al.: Sacroiliac joint dysfunction: evaluation and management. Clin J Pain, 2005, 21: 446-455. [Medline] [CrossRef]

2) DonTigny RL: Pathology of the sacroiliac joint and its effect on normal gait. J Orthop Med, 2005, 27: 61-69.

3) Brolinson PG, Kozar AJ, Cibor G: Sacroiliac joint dysfunction in athletes. Curr Sports Med Rep, 2003, 2: 47-56. [Medline] [CrossRef]

4) van Wingerden JP, Vleeming A, Buyruk HM, et al.: Stabilization of the sacroiliac joint in vivo: verification of muscular contribution to force closure of the pelvis. Eur Spine J, 2004, 13: 199-205. [Medline] [CrossRef]

5) Neumann DA: Kinesiology of the musculoskeletal system: foundations for physical rehabilitation. St Louis: Mosby, 2009.

6) Carter JB, Banister EW: Musculoskeletal problems in VDT work: a review. Ergonomics, 1994, 37: 1623-1648. [Medline] [CrossRef]

7) Yoo WG: Effects of individual strengthening exercises on subdivisions of the gluteus medius in a patient with sacroiliac joint pain. J Phys Ther Sci, 2014, 26: 1501-1502. [Medline] [CrossRef]

8) Cibulka MT: The treatment of the sacroiliac joint component to low back pain: a case report. Phys Ther, 1992, 72: 917-922. [Medline] 